\title{
TAX SAVINGS FOR EXPORTERS UNDER THE NEW FOREIGN SALES CORPORATION OPTION
}

\author{
C.D. Baron and M.P. Dillaway \\ Department of Accounting \\ New Mexico State University
}

\section{INTRODUCTION}

Many factors must be considered in deciding whether it would be profitable for a U.S. business to export its products to customers in foreign countries. One factor sometimes overlooked is the potential for higher profit margins when export sales are channeled through a special corporation permitted by the income tax laws. This article summarizes the main features of this tax device as provided for in the Tax Reform Act of 1984 (1).

\section{DISC's Replacement: The Foreign Sales Corporation}

Until 1984, the tax law provided for a system of tax deferral for U.S. businesses selling their products in foreign markets. Under this system, special corporations known as Domestic International Sales Corporations, or DISCs, were created (usually as a wholly owned subsidiary of a parent corporation) and interposed between the manufacturer or distributor and its foreign customer. Using this device, the tax on a portion of the income from export receipts, generally 42.5 percent, could be deferred indefinitely until distribution to the DISC's shareholders.

DISCs came into the tax law in 1971 and have been widely used by exporting companies since that time. In 1979, for example, more than 7,208 DISC tax returns were filed, accounting for almost $\$ 99$ billion of gross export receipts and $\$ 6.4$ billion in DISC net income, of which more than $\$ 2$ billion was tax deferred.

Since its enactment, the DISC had been the subject of an ongoing dispute between the United States and certain other signatories of the General Agreement on Tariffs and Trade (GATT), who have contended that the DISC amounts to an illegal export subsidy. After a decade of debate, the U.S.

(1) This article summarizes selected portions of a complex part of the tax code and is not intended as a complete discussion of the subject. Its purpose is to acquaint the reader in a general way with the tax savings potential of a DISC or FSC. Readers interested in specific applications to their own business should consult the tax literature or their tax adviser. 
agreed to enact tax legislation that would address the concerns of the other GATT members. Relevant provisions of the Tax Reform Act of 1984 (the Act) are the outcome. In the Act, signed into law in July, this system of DISCs is to be replaced (but not entirely abolished) by the Foreign Sales Corporation, or FSC. The underlying concept of the rules change is that only foreign-source income - income attributable to economic activities occurring outside the United States - is to be exempt from U.S. taxation. Accordingly, exporters are required to establish "foreign sales corporations" to administer their export sales activities occurring outside U.S. territorial limits in order to qualify for the partial tax exemption.

A broad outline of the changes are summarized as follows:

1. The act provides that a portion of the export income of an eligible FSC, generally 32 percent, will be exempt from federal income tax.

2. It allows a domestic parent corporation a 100 percent dividendsreceived deduction for dividends distributed from the FSC out of exempt foreign trade income. Thus, the export profits of the FSC can be repatriated to the parent as soon as possible without any adverse U.S. tax consequences.

3. The accumulated tax-deferred income of a December 31, 1984 DISC will be deemed previously taxed income, exempting it forever from taxation.

4. Small business exporters may find it difficult to comply with certain of the foreign presence requirements of the FSC rules. The Act provides, therefore, two options to eligible small businesses: the interestcharge DISC and the small FSC.

These main provisions will now be explained in greater detail.

\section{Formation and Operation of a FSC}

To qualify as an FSC, a corporation must have adequate "foreign presence"; that is, it must be created, managed and operated to a substantial degree outside the United States. This is a major departure from the previous DISC concept where the tax vehicle could be a mere shell corporation on the domestic parent's books.

When creating an FSC for tax purposes, three foreign presence requirements must be met. First, the FSC must be incorporated under the laws of a qualifying country (generally tax-treaty countries, but the Treasury Department is to issue a list of countries that qualify). Second, the FSC must maintain an office outside of the U.S. where a complete set of tax and accounting records is kept. Third, the FSC's board of directors must include one individual who is not a resident of the U.S., although that individual may be a U.S. citizen. 
After formation of the FSC, additional foreign presence tests must be met during each taxable year in order to maintain its tax status. For example, as evidence that the FSC is managed outside of the U.S., all meetings of its board of directors must be in a foreign country; and its principal bank account must be maintained in a foreign bank.

In order for export transactions to produce foreign-source income subject to tax exemption, a substantial amount of the export sales effort must take place outside of the U.S. This requirement is satisfied when both parts of a two-part test are met. In the first of these, employees of the FSC or their agents must have performed either the solicitation, negotiation, or finalization of the export sales contract activity outside of the U.S. Generally, this test is applied on a per customer, per contract basis.

In the second part of this foreign presence test, at least 50 percent of the direct costs of initiating, processing and settling the export sale transaction must be traceable to activities performed outside of the U.S. The FSC may contract with its U.S. parent or with any other party, related or unrelated, to act as its agent in carrying out these activities, provided they are substantially performed outside of the U.S.

\section{Tax Treatment of FSC Income}

Income of the FSC subject to exemption is restricted to foreign trading income derived from export sales. Investment income or income from intercompany transactions is not included. Complications aside, the foreign trading income of the FSC is the difference between the selling prices paid by foreign customers for export property sold by the FSC and the cost prices for those goods paid by the FSC to its suppliers-its related parent manufacturer in the typical case. Export revenue eligible for tax exemption is deliberately similar to the previous DISC concept of qualified gross receipts, being derived from the sale or lease of qualified "export property." Export property represents property that is manufacturer, produced, grown or extracted in the U.S. for sale to an FSC in the ordinary course of business for direct use of consumption outside of the U.S. Such property must not have more than 50 percent of its fair market value attributable to articles imported into the U.S. Four types of property are specifically excluded from being classed as export property, the most notable being (1) oil, gas or any primary product therefrom and (2) intangible assets, such as patents, copyrights, designs and like property.

The unit cost prices to be matched against the export gross receipts in computing FSC foreign trading income are derived from one of two approaches available to the taxpayer. In one approach, the general corporate tax rules for arms-length pricing of intercompany transfers is to be used. In the other approach, special administrative pricing rules contained in the Act can be used. The mechanics of intercompany pricing are too detailed to 
review in this summary, although many of the marginal costing, no-loss, and transaction grouping rules familiar to DISC users are carried over into the new legislation.

Foreign trading income of the FSC derived as outlined above is composed by definition of two parts: (1) so-called foreign-source income, which is exempt from taxation; and (2) U.S.-source income, which is taxed currently at the FSC level. The exact portion of the FSC income that is category (1) and exempt depends on the intercompany pricing approach chosen by the taxpayer. Generally, approximately 32 percent of FSC trading income is exempt from taxation.

\section{Small Business Use of the FSC}

Small businesses are likely to find the foreign presence requirements for creating and operating an FSC extremely burdensome. For this reason, the Act provides relief in two forms: (1) the interest-charge DISC, and (2) the designated small FSC.

For those small business exporters having less than $\$ 10$ million in gross export receipts who are presently using a DISC, special provisions apply that should be analyzed carefully in formulating a sound tax planning strategy. Under the Act, companies may elect to continue their existing DISCs and are not required to convert to an FSC. This avoids the need to meet the foreign presence requirements of the latter. Furthermore, certain provisions of the previous DISC rules have been eliminated, which makes the DISC vehicle even more attractive for the small exporter. For example, the 57.5 percent deemed distribution and the incremental income rules are no longer applicable to existing DISCs. As a result, substantially all of the DISC income attributable to $\$ 10$ million of gross export receipts (for a year after 1984) is deferred. If export receipts for a particular post-1984 year exceed this amount, the DISC will not be disqualified; there would merely be no deferral of tax on the excess.

However, unlike the previous-law DISC, an interest charge will be imposed on shareholders of the DISC in lieu of tax. The interest charge is computed on the accumulated post-1984 deferred tax liability of DISC shareholders using a base period Treasury Bill interest rate. Generally, all other previous-law rules applicable to DISCs remain applicable under the new Act.

As an alternative to the interest-charge DISC, or for those small business exporters without an existing DISC, the Act provides for electing to be treated as a "small FSC." Under these circumstances, a small FSC need not meet the foreign presence requirements outlined previously. However, in determining the amount of exempt foreign-source income, any export gross receipts in excess of $\$ 5$ million will not be taken into account. The small FSC is allowed to select the export transactions to be applied to the $\$ 5$ million cap, 
enabling the taxpayer to assign high profit margin export transactions to the tax-exempt portion of FSC income.

\section{Transition Rules for Existing DISCs}

The last taxable year of each DISC beginning during 1984 is deemed to have closed on December 31, 1984. The corporation's DISC election is deemed revoked on December 31, 1984. If a DISC did not elect to be an "interest-charge DISC" by January 1, 1985, it is referred to as a former DISC. Any amounts distributed by a former DISC, including an "interest-charge DISC," after July 1, 1985, shall be treated as first out of current profits, and then out of previously taxes income. (Any distributions before July 1, 1985, shall be considered as previously taxed income.)

\section{Establishing and Electing Status as an \\ FSC, or Small FSC}

The election to be an FSC or small FSC requires the filing of Form 8279. This election must be made within 90 days after the beginning of the taxable year.

For those corporations which were in existence before June 30, 1985, the election to be qualified as an FSC must be made during a 90-day period prior to the first day of the taxable year. Once created, the new FSC continues in effect until it is explicitly revoked by the taxpayer or fails to meet the qualifying requirements for five consecutive years. If qualified status is revoked, it can be reinstated at a later time.

\section{Summary and Conclusions}

Exporting products to foreign markets is a complex but potentially profitable business undertaking. One important factor to consider in deciding whether to enter or to expand foreign operations is the potential tax savings of using a special tax-status corporation to channel the export sales.

Under previous tax laws, exporters could use the DISC corporation. The Tax Reform Act of 1984 retains limited use of the DISC for small businesses and introduces the FSC corporation. Formation and operation of an FSC requires that a substantial portion of export sales activity must take place outside of the U.S. If this occurs, approximately 32 percent of FSC income derived from foreign trade can be exempt from U.S. taxation. A small business exemption from the burdensome need to locate sales activity offshore is provided for in the Act. For other businesses contemplating export operations, details of the FSC provisions should be carefully considered. The tax benefits resulting could well be sufficient to affect the business decision. 